\title{
Geological Hazards During Construction and Operation of Shallow Subway Stations and Tunnels by the Example of the Kharkiv Metro (1968-2018)
}

\author{
Viacheslav Iegupov*, Genadiy Strizhelchik, Anna Kupreychyk, Artem Ubiyvovk \\ Department of Geotechnics and Underground Structures, Kharkiv National University of Civil Engineering and Architecture, \\ 40 Sumska Street, Kharkiv, Ukraine
}

\begin{abstract}
Scientific, technical and practical problems have been considered in relation to geological hazards during construction and operation of metro objects such as shallow subway stations and tunnels. Analysis of five decades of the experience of construction and subsequent operation of the Kharkiv metro in rough engineering and geological conditions by construction of tunnels at shallow depths under the existing urban development allowed detecting and systematizing a set of the most essential adverse conditions, processes and phenomena. The main geological hazards are related to the expansion of quicksands, possibility of "flotation" of the underground structures, barrage effect, subsidence of the soil body by long-term dewatering, undermining of the built-in territories and difficulties by tunneling in technogenic fill-up grounds when crossing ravines and gullies. Most problems occur in the territories with a high groundwater level: geological risks in these areas increase, and serious incidents occur by sudden adverse changes of hydrodynamic conditions. Zones of high, medium and low geological hazards have been identified. Geological hazards have been defined at the section planned for extension of the metro line, for which calculations of the affluent value were made based on the barrage effect of tunnels on the groundwater flow. Taking into account the possibility of emergence of engineering and geological processes and prevention of their development provides safe and reliable construction and operation of shallow metro systems. The obtained results of evaluation of geological hazards can be used by designing and construction of underground objects in similar conditions.
\end{abstract}

Keywords: underground, shallow tunnels, complex conditions, weak soils, accidents

\section{Introduction}

Geological hazards can be determined by natural causes (seismic phenomena, volcanic eruptions, natural shift of soil or snow on slopes etc.) or can be caused by human activities (undermining of territories, technogenic landslides, suffosion sinkholes, flooding, barrage effect etc.). Evaluation of geological hazards is conducted by studying natural geological, hydrogeological, geomorphological and/or ecological conditions, processes and phenomena as well as the peculiarities of anthropogenic activity, whose combinations may pose a direct or potential threat to human life, health and property or to the environment.

Various negative impacts can often be observed during construction of underground structures, especially if they are as massive as metro systems (Vlasov et al 2000, Abramchuk et al 2005). Experience shows that various geological hazards and geotechnical issues may occur during construction of metro systems at shallow depths (Brodin 1998, Eskesen and Kampmann 2000, Vlasov et al 2000). These issues are partially determined by geological characteristics of territories and tunneling methods and partially by peculiarities of the use of said territories as part of city-planning efforts (Strizhelchik 1992, Bondarenko and Roenko 1996, Bielecki and Berger 1998, Giginyak 2009).

Metro lines are designed for mass transportation of passengers, which is why they are built mostly in densely populated areas and central parts of large cities. One of such objects is the metro system in the city of Kharkiv, Ukraine. Construction of metro systems in conditions of the existing urban development, especially in rough engineering and geological conditions, results in a number of scientific, technical and practical problems. These problems are mainly related to the need for tunneling under or near existing buildings, especially in the areas with weak, watersaturated soils, and to the occurrence of unfavorable processes that affect buildings and structures, both during construction and operation of metro systems (Strizhelchik and Iegupov 2017).

When undermining or tunneling close to objects, it is necessary to estimate the stability of buildings and structures already during the stage of design and survey works. The ability of soils to soften under vibration dynamic influences and the possibility of emergence of dehydration-

\footnotetext{
* Corresponding Author: Viacheslav Iegupov, slavaegu@ gmail.com

Received May 14, 2018; Revised August 14, 2018; Accepted August 20, 2018; Available online October 30, 2018
} 
gravitational subsidence of the surface during dewatering must be assessed. Survey information forms the basis for multi-variant design solutions. In each case, the problems of reliability, safety and economic efficiency of structures must be solved. If we take into account that every point of the geological space is unique, the development of design solutions is a rather complex and science-intensive task. One needs to take into consideration the stability of pit walls by cut-and-cover tunneling and the stability of tunnel arches and headings by deep-bore tunneling. It is necessary to assess the vibration influence of moving trains on existing buildings and structures, which can occur during the metro operation. These are only some of numerous practical issues related to construction of such a complex structure as a metro system.

We have conducted the analysis of geological hazards occurring during construction of metro systems at shallow depths of up to $10-15 \mathrm{~m}$ from the soil surface using the example of the Kharkiv Metro. This article is intended to clarify a number of issues encountered during construction and subsequent operation of the Kharkiv Metro, ways of solving said issues and taking them into account during new construction.

\section{Brief Description of the Kharkiv Metro}

The Kharkiv Metro system comprises three active lines with a total length of $38.45 \mathrm{~km}$ (40.87 km including headshunts), 30 underground stations with three transfer hubs in central districts of the city (Fig. 1).

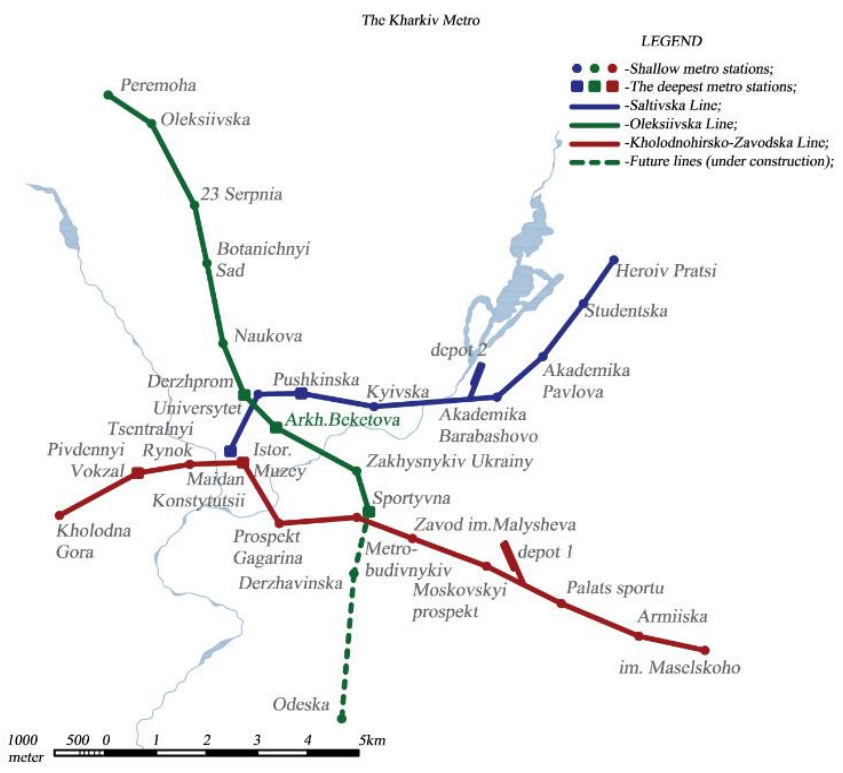

Figure 1. Map of the Kharkiv Metro lines

Among 19 metro systems of the former USSR, the Kharkiv metro was the fourth by the length of lines after the metro systems in Moscow, Saint Petersburg and Kyiv. On work days, the Kharkiv Metro transports on average 800,000 passengers, and on some days, this number exceeds 1 million. Over the entire operation period since 1975, more than 7 billion passengers have been transported by the metro.

Construction of the Kharkiv Metro began in 1968, and in 1975, the first eight-station segment was put into use. The line crossed the city from west to east. The initial line went through the city center and connected three railway stations of Kharkiv (Pasazhyrskyi, Levada, Balashovskyi) and its bus station. Currently, 30 stations are operating, which are located on three lines: Kholodnohirsko-Zavodska (red line, the first segment constructed in 1968-1978), Saltivska (blue line, the second segment constructed in 1977-1986) and Oleksiivska (green line, the third segment constructed in 1984-2016). Support facilities include two locomotive depots (Moskovske and Saltivske), while the third depot, Oleksiivske, is in the design and construction phase.

Where possible, tunneling of the metro system was conducted using the more cost-effective cut-and-cover method. The deep-bore tunneling method with the use of a tunneling shield was applied in central districts with highdensity development as well as in rough geological and hydrogeological conditions (e.g., in flood plains and under river beds). The majority of stations have been built using the cut-and-cover method.

\section{Description of Natural Conditions}

Geomorphological conditions of Kharkiv (Fig. 2) are characteristic of a gently undulating loess plain dissected by river valleys, ravines and gullies.

Absolute relief elevations in the territory of the city gradually decrease from $200 \mathrm{~m}$ in the north to $95 \mathrm{~m}$ in the south. River valleys have a complete set of NeogeneQuaternary terraces typical for an extraglacial zone. The geomorphological structure of the city territory constitutes

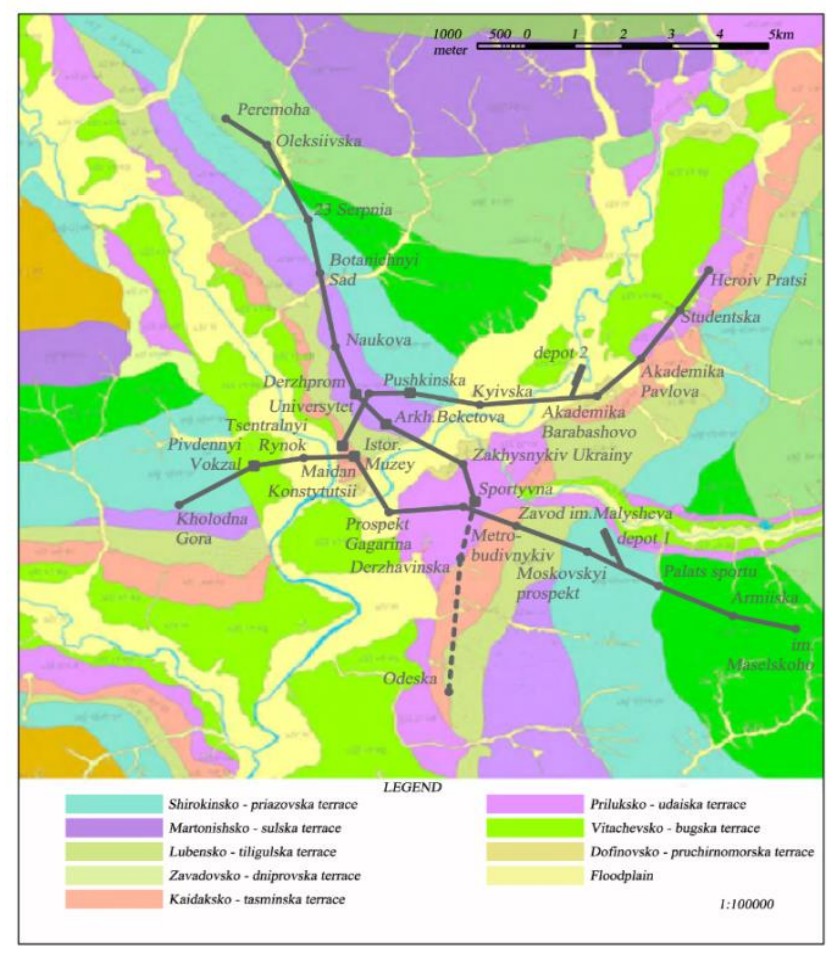

Figure 2. Geomorphological map of Kharkiv 
several complexes of fluvial terraces of the Dnieper series. The complex of young, low terraces, including the Holocene floodplain, the Vitachiv-Bug and the Pryluky-Uday terraces, has developed in the valleys of main rivers (Kharkiv, Lopan, Udy) as well as locally, in the valleys of their smaller tributaries (Nemyshlia and Sarzhynka rivers, several ravines and gullies). These ravines cut through the complex of older, higher terraces, starting from the Kaidak-Tiasmyn terrace, which form the geomorphological structure of the territory at higher elevations.

Sedimentary deposits, predominantly from the Quaternary and Paleogene periods, make up the geological structure of the city territory. Metro structures on the Holocene floodplain and the low Pryluky-Uday terrace above the floodplain are located mostly in the layer of alluvial sands and only partially in the alluvial-deluvial loamy grounds. Stations and tunnels on the higher PrylukyUday, Lubensk-Tylihul and Zavadiv terraces are located predominantly in the loess-like loams and eolian-deluvial sandy-loam soils. Underground structures are located in the Verkhne-Kievsky Paleogene clay soils.

In the hydrogeological cross-section of sedimentary deposits being the environment where the metro objects are constructed, there are two main aquifers, which often create a unified aquifer complex. Aquifers can have various degrees of difficulty or freedom of hydraulic connection between each other. The Quaternary aquifer is associated with Holocene sands, sandy clays and loams as well as sands and sandy clays from older Quaternary terraces. The aquifer of the Obukhiv Paleogene deposits is associated with sands, fissured sandstones and siltstones interbedded in complex forms in the layer of clays and dense aleurites. The aquifer complex is subartesian and phreatic. The feeding of the Quaternary aquifer has natural and technogenic character due to infiltration of precipitation as well as emergency and systematic leaks from the water supply network. The underground flow in the territory of the city generally occurs from drainage divides to the valleys of the Lopan, Kharkiv and Udy rivers that drain groundwater.

Hydrological regime of rivers is characterized by a clearly defined spring flood, significant and long-term low water level in summer and autumn; sometimes low and short-term rainfall floods can be observed.

Typical for Kharkiv are multiple territories with a high natural groundwater level, these territories are constantly or periodically flooded by groundwater. They are associated with floodplains and low terraces of rivers formed in fine dusty, loamy and dirty sands. The groundwater level may be at the depths from 0 (in the immediate vicinity of river beds and wetlands in the floodplain) to 5 and more meters with increased distance from rivers (Fig. 3).

\section{Negative and Hazardous Conditions, Processes and Incidents}

Geological principles of engineering geodynamics, classification of geological processes and their technogenic equivalents are described in major works, e.g., Theoretical Bases of Engineering Geology 1985, Bondarik 2007.
Information on modern distribution of geodynamic processes in the territory of Ukraine can be found in several works, e.g., Ecological Geology of Ukraine 1993, Demchyshyn 2004, Iegupov and Kichaeva 2016, Strizhelchik at al 2017.

The experience of constructing underground structures in rough engineering and geological conditions in Kyiv, Moscow, Saint Petersburg, Kharkiv and other cities, as well as the accidents that have occurred there and methods for the emergency response and recovery are described in several works: Vlasov et al 2000, Abramchuk et al 2005, Strizhelchik and Iegupov 2017, etc.

We have conducted the analysis of combinations of natural conditions and construction objects, such as shallow subway stations and tunnels, which allowed us to identify the most typical and hazardous negative natural and technogenic processes and phenomena that occurred during construction and operation of the Kharkiv Metro (Table 1).

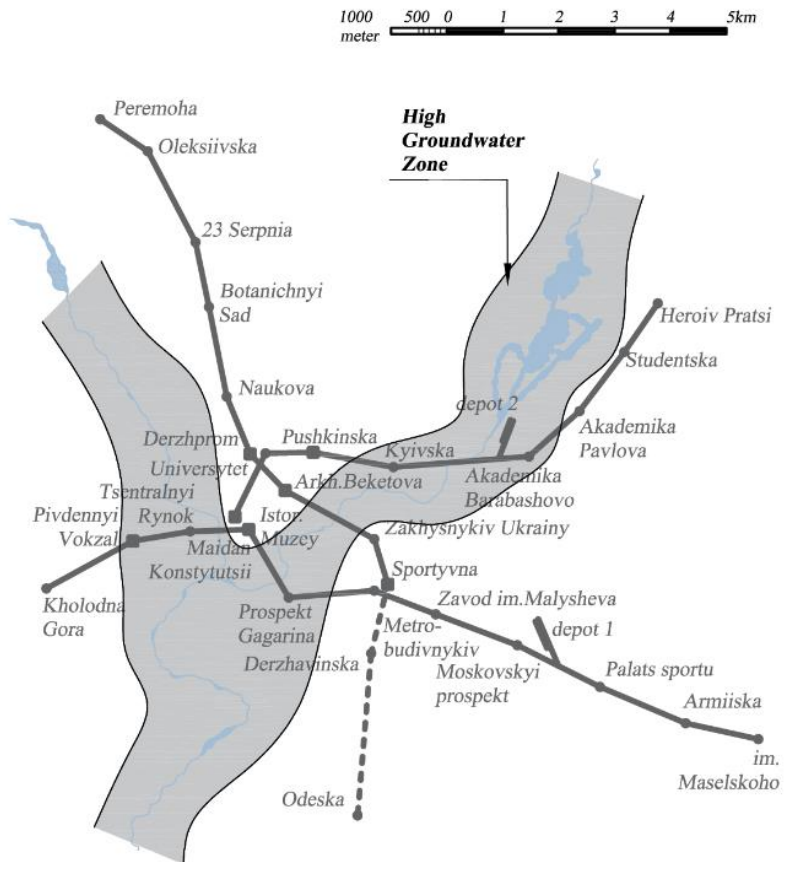

Figure 3. Map of territories with high natural groundwater level

\section{Quicksands}

Spreading of quicksands is associated with floodplains and low terraces of rivers formed in fine dusty, loamy and dirty sands. The groundwater levels may be at the depths from 0 (in the immediate vicinity of river beds and wetlands in the floodplain) to 5 and more meters with increased distance from rivers. Less often, sands with quicksand properties occur as lenses and other complex inclusions in the layer of Paleogene clays. Quicksands and the possibility of "flotation" of underground structures present the greatest hazard in floodplains of rivers.

According to Zlochevskaya 1969 and Abelev 1983 quicksands are water-bearing loose soils, usually sands and loamy sands, which can change to a free-flowing state by 
Table 1. Hazardous and negative natural and technogenic processes and phenomena during construction and operation of the Kharkiv Metro

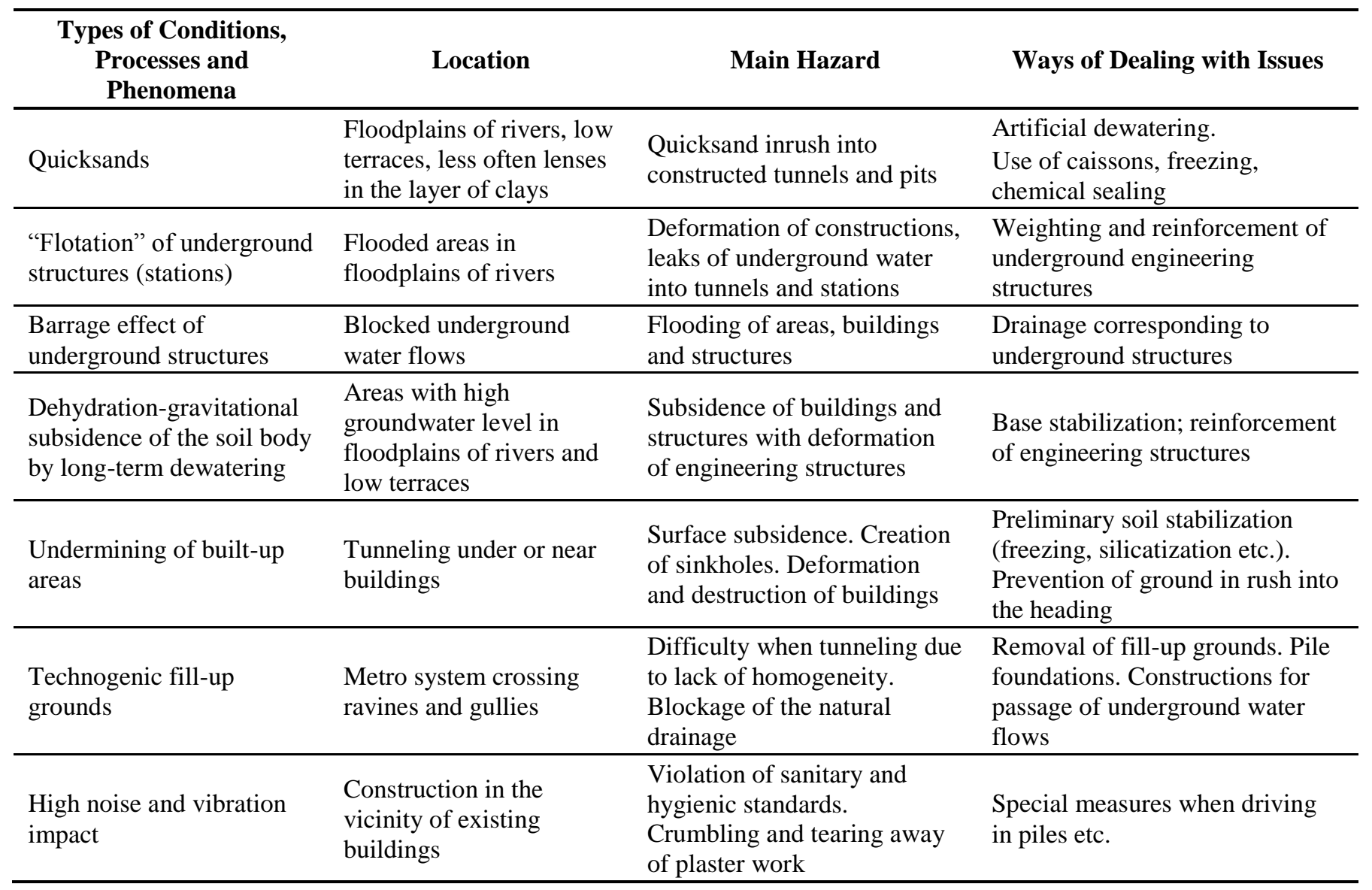

high water filtration gradients or mechanical vibration impacts (thixotropic liquefaction). In the process of uncovering through various mining and excavation works, quicksands become loose and start moving as a heavy viscous liquid, virtually a suspension similar to a very thin paste. Quicksands make construction and mining works very difficult. During surface excavations and underground tunneling, quicksands tend to rush into the opening free space (Fig. 4).

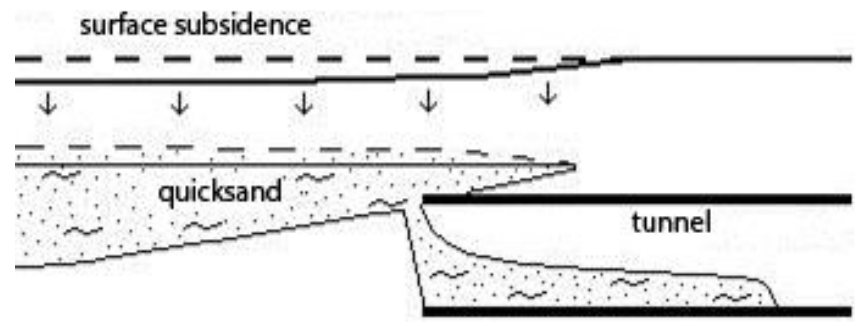

Figure 4. Diagram of a quicksand inrush into a tunnel under construction

When deep-bore tunneling is conducted in areas with water-bearing sands, there is a risk that quicksand properties will manifest themselves, which could lead to flooding of the tunnel. A disaster took place in Saint Petersburg, Russia, when a tunnel became flooded due to quicksands (Vlasov et al 2000). A similar case (fortunately, without victims) occurred at the first construction section of the Kharkiv Metro between the Prospekt Haharina and Sportyvna stations. A tunnel section with the length of approximately $150 \mathrm{~m}$ became flooded with water-bearing sands and had to be abandoned. This was more cost-effective and advisable from the technical point of view, and a parallel tunnel had to be constructed nearby.

There are several ways of combating quicksands, which can be divided into four groups:

1 - artificial dewatering of quicksands during the construction period: open water pumping from pits, wellpoint dewatering along the pit edges;

2 - shoring of pits by creating a sheet pile wall for protection against quicksands;

3 - stabilization of quicksands by changing their physical properties: silicatization, cementation, freezing and electrochemical consolidation;

4 - tunneling using the caisson method.

Artificial freezing is conducted by building a system of interconnected boreholes around a pit or a tunnel and applying special refrigerating units to create circulation of a refrigerant, e.g., $\mathrm{CaCl}_{2}$ solution cooled down to $-20^{\circ} \mathrm{C}-40^{\circ} \mathrm{C}$. This establishes a zone of frozen impermeable soil around the construction area. Earlier, it was thought that freezing of 
quicksands is a temporary and not very reliable measure. However, the construction experience of several metro objects, in particular, the Pivdennyi Vokzal station, has demonstrated high effectiveness and reliability of freezing quicksands by construction in conditions of high-density urban development (Fig. 5).
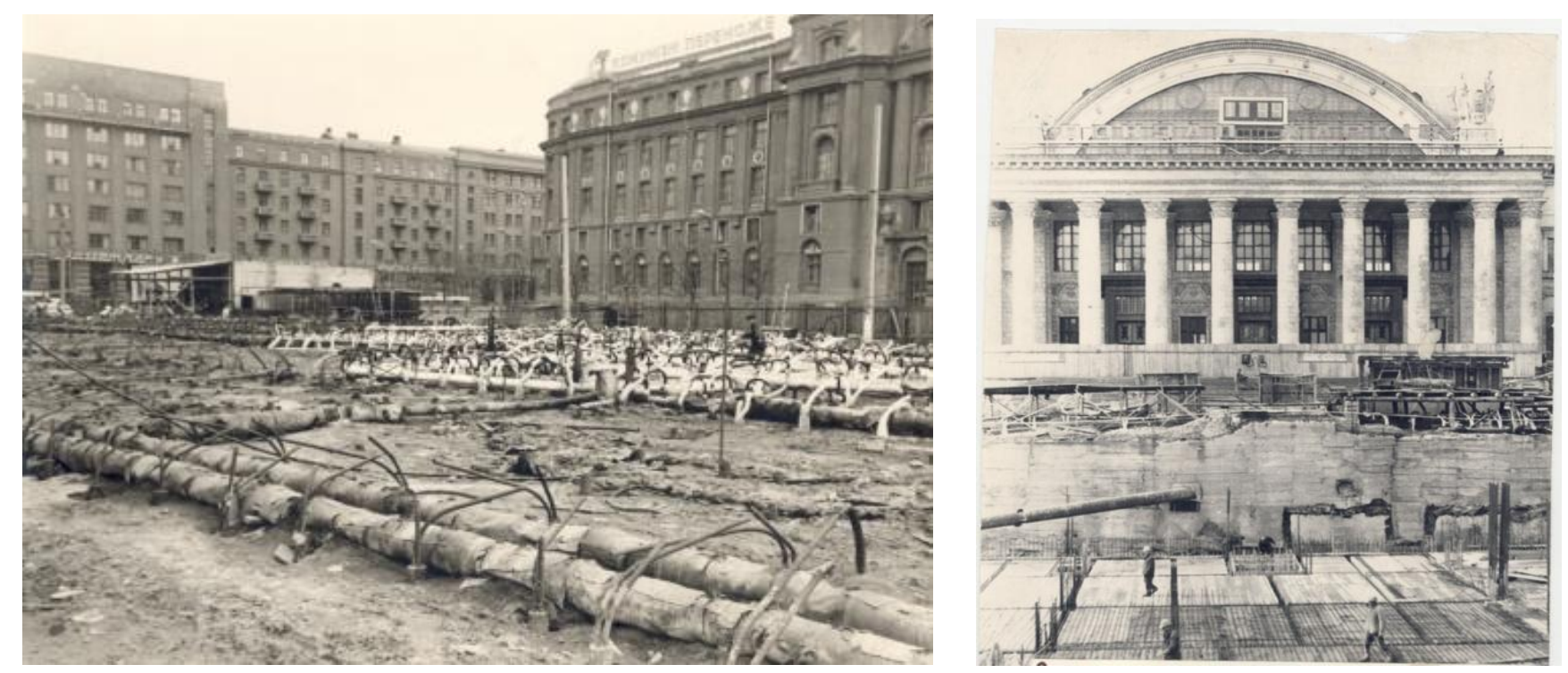

Figure 5. System for freezing quicksands during construction of the Pivdennyi Vokzal metro station in Kharkiv (picture from 1971). Photo source: http://www.mirmetro.net/kharkiv/cruise/01/11_pivdenny_vokzal

Freezing of water-bearing grounds with weak structural bonds was used instead of traditional construction dewatering, which could cause significant deformation of existing buildings and structures due to ground dehydration.

Ground freezing works were conducted continuously for five years (!). During this time, $24 \mathrm{~km}$ of boreholes were drilled and fitted, out of which $15 \mathrm{~km}$ were used for station tunnels constructed using the deep-bore method. To build the station entrance hall, a $40 \times 40 \mathrm{~m}$ pit with the depth of up to $13 \mathrm{~m}$ was excavated, which was fenced off by a bearing wall made of sand and ice. This wall, which was basically frozen quicksand with the thickness of up to $6 \mathrm{~m}$, was sunken into the underlying impermeable layer of clay. Effectiveness of this method can be confirmed by the fact that the design allowed for $100 \mathrm{~mm}$ settlement of the massive building of the Pivdennyi Vokzal railway station above the metro tunnels, but the real settlement amounted to just $8 \mathrm{~mm}$.

When creating vertical or horizontal underground tunnels in potential quicksands, caisson chambers can also be used. Increased pressure inside of them balances out hydraulic pressure of the quicksand. Caisson is a retaining construction that allows creating a workspace in quicksands; water inside is displaced by pressurized air. The caisson method was used to construct main line tunnels in quicksands under the Kharkiv river between the Maidan Konstytutsii and Prospekt Haharina stations. For the period of tunneling under the river bed, water was drained from the Kharkiv river. In addition to a caisson, chemical ground stabilization was used.

The use of the caisson method in areas of potential quicksand development decreases the risk of tunnel flooding, but results in increased pore pressure in the ground and higher groundwater level and can cause flooding of adjacent underground structures. There have been cases when the asphalt pavement heaved due to breakout of pressurized air to the surface.

\section{6 "Flotation" of Underground Structures (Stations)}

Another extremely dangerous phenomenon that can occur on floodplains is "flotation" of underground structures by sudden changes in the groundwater level. This was the case with the Prospekt Haharina and Tsentralnyi Rynok stations.

Construction of the Prospekt Haharina station was conducted using the cut-and-cover method at shallow depths and in confined space - the pit was located between buildings. The hydrogeological conditions were very harsh: very soft alluvial grounds with significant amount of groundwater. For instance, when digging a pit, one of the bulldozers almost drowned in the thixotropically liquefied quicksand and had to be pulled out using a powerful crane. To decrease the groundwater level for the construction period, 48 wellpoints were drilled along the perimeter of the station pit, and four powerful pumps with the capacity of $100 \mathrm{~m}^{3} / \mathrm{h}$ were installed. When the station was almost ready, and construction dewatering was stopped, the groundwater level began rising, and the measurements showed that the station platform level was $140 \mathrm{~mm}$ higher than planned and built. To return the platform to the previous position, the structure was loaded with additional reinforced concrete slabs. This allowed bringing the structure back to the design reference marks.

The Tsentralnyi Rynok station is located effectively in the old channel of the Lopan river with high natural 
groundwater level. For 20 years (1975-1995), the station was operated without any complications. However, in June 1995, there was an extremely heavy rain in Kharkiv, after which the groundwater level in the vicinity of the station began rising quickly and reached more than five meters above the level of the rail. Because of this, the station structure literally began to "float" to the surface. Numerous leaks appeared in tunnels, and the platform rose significantly so that its floor was much higher than the level of the train doors. Cracks emerged in the platform foundation. It was decided to immediately start emergency restoration and recovery works. Seven wellpoints were made on the surface. Reinforcement of the station structure was conducted without any changes to the operation mode except for restrictions regarding the speed at which trains should move. Within a year, $404 \mathrm{~m}^{3}$ of concrete and 35 tons of rebars were placed under the platform, and the trough part of the station was injected with 185 tons of cement mixture. To reinforce the arch and make the structure more rigid, a row of columns was installed along the station platform. These works were conducted in July 1996 in record time, in just ten days. Massive efforts were worth it the level of the station platform was restored, deformation and leaks ceased. After that, the Tsentralnyi Rynok station received its modern design (Fig. 6).
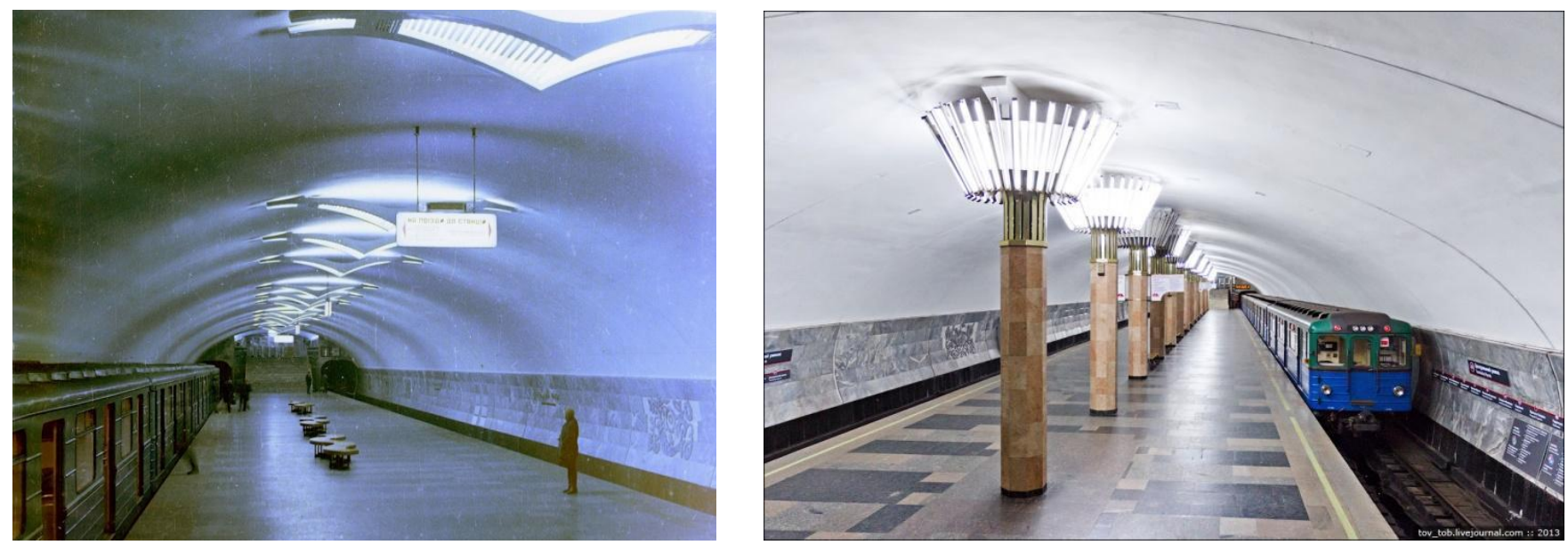

Figure 6. Tsentralnyi Rynok station before and after reconstruction. Photo: http://www.mirmetro.net/kharkiv/cruise/01/12_centralny_rynok

When designing the Saltivska (blue) metro line, it was obvious that the most difficult construction area would be the section between the Kyivska and Akademika Barabashova stations where the tunnels had to cross the floodplain of the Kharkiv river. Considering the difficult experience obtained when facing the challenges related to groundwater and quicksands during construction of the first (red) line in similar conditions, the designers made an unusual decision. Instead of tunneling under the quicksands of the floodplain and bed of the Kharkiv river and using the caisson method, dewatering etc., it was decided to build a closed metro bridge (tunnel) above the surface. This method not only allowed avoiding labor-intensive dewatering works, but also turned out to be more cost-effective and simpler in technical terms. The Kharkiv metro bridge was built and put into service in 1984 as part of the initial section of the Saltivska line. This covered bridge with a heat-insulated gallery in the form of a gigantic 980 meters long half-pipe is unique in the countries of the former USSR (Fig. 7).
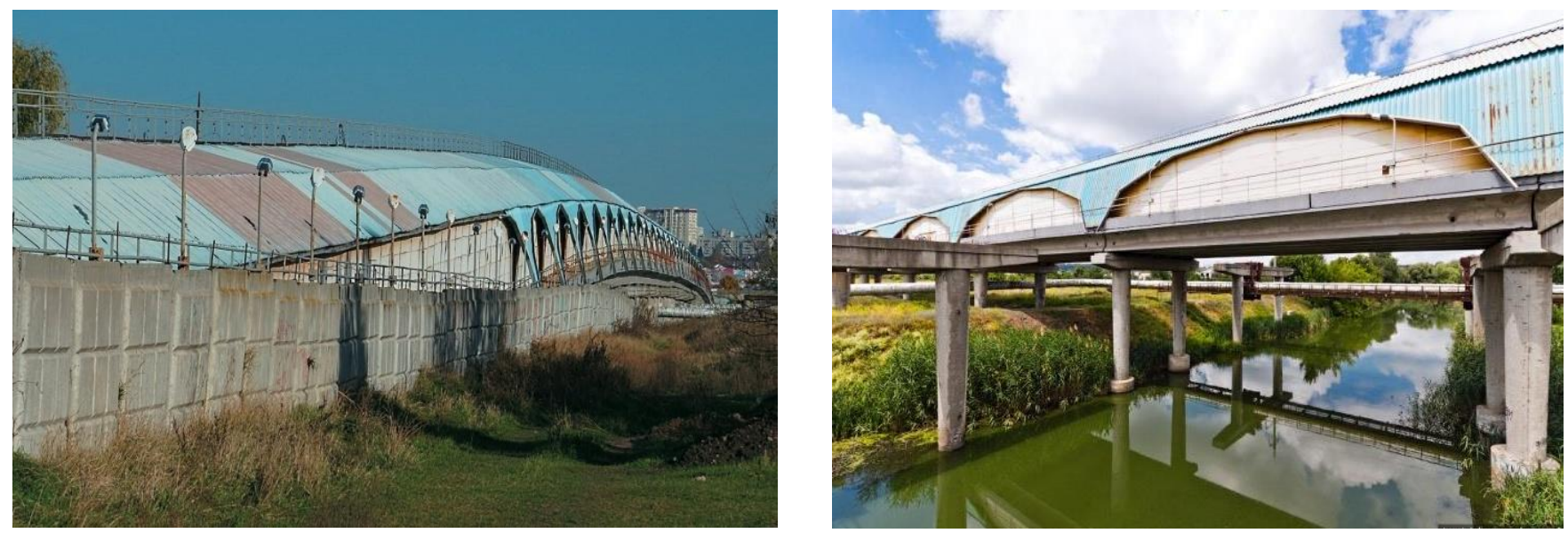

Figure 7. Kharkiv metro bridge. Photo source: http://www.mirmetro.net/kharkiv/facts/metromost 


\section{Barrage Effect of Underground Structures}

The barrage effect or groundwater ascent occurs when the underground filtration flow is blocked by various underground structures or underground parts of buildings and structures built above ground. The barrage effect has been observed in a number of objects (metro tunnels, stations), where the groundwater level rose and, in some cases, resulted in flooding of areas and adjacent buildings and structures, deformation of earth foundations and other adverse consequences. On the Saltivska (blue) metro line, ground-water ascent occurs in the section between the Akademika Barabashova and Akademika Pavlova stations.

The Akademika Barabashova station is located in the floodplain quicksands of the Kharkiv river, i.e., in difficult hydrogeological conditions. The groundwater level lies here at the depth of $20-50 \mathrm{~cm}$; the water inflow is very heavy. During construction of the station, dewatering needle-filter units were placed along the entire length of the construction site, and numerous deep wells were drilled for pumping out water. It was estimated that, should the pumps be turned off, the entire pit would become flooded in just 20 minutes.

To prevent the barrage effect and preserve the natural groundwater level, a special drainage system was constructed on the side of the groundwater flow behind the tunnel lining. The drainage within the station was made from perforated cast-iron pipes, and along the tunnels, from asbestos-cement pipes with two filter layers - one from fine gravel, and the other from coarse-grained sand. Water from the drainage is spilled into the river via pumping stations.

\section{Dehydration-Gravitational Subsidence of the Soil Body by Long-Term Dewatering}

Areas with high natural groundwater level also include sections where dehydration-gravitational subsidence of the soil body and earth surface occurred due to long-term dewatering. Uneven settlement of buildings with shallow foundations located close to dewatering units can sometimes amount to more than $15 \mathrm{~cm}$, which significantly exceeds the standard permissible values. In several cases, the engineering structure of small old buildings had to be reinforced with metal bandages. When dewatering works are finished, the situation usually normalizes.

\section{Undermining of Built-in Territories}

In terraces of rivers above the floodplain, geological hazards are mostly related to undermining of territories. The geological structure comprises predominantly loess-like loams with an underlying layer of sands. The groundwater level lies at the depths of 4-8 m. Geological hazards in this zone have to do with possible adverse phenomena (overbreaks) by deep-bore tunneling under the existing development as well as with difficulties when crossing ravines and gullies.

Undermining area is an area where uneven quick or slow subsidence of the earth surface and ground displacement in foundations of buildings and structures may occur due to underground mining activity. Underworking of areas usually takes place during underground mining works (creation of shafts, drifts and galleries) when extracting coal and other mineral resources, as well as during underground tunneling, construction of collectors, underpasses and other underground objects in cities.

As a result of underworking, smooth shift throughs (subsidence) of the earth surface or mining damage can occur. These are areas that collapse under the influence of underground mining activity. Shift through is a surface area where horizontal and vertical shifts and deformations (slopes, distortion, extension, compression) may occur due to under-ground mining activity. Deformation values depend on the depth at which mining works are conducted and the volumes of extracted ground by tunneling or construction of under-ground structures.

Shift through boundary is a line connecting points where the earth surface subsided by $\sim 10-15 \mathrm{~mm}$. Within the shift through, there is a dangerous shift zone, where shifts and deformations present a direct threat to buildings and structures in the undermining area, and a fractured zone on the edges of the soil body, which has a lesser impact on the surface objects. Dimensions of these zones depend on mechanical properties of the soil body. Figure 8 below shows a diagram of the surface deformation in the form of a shift through.

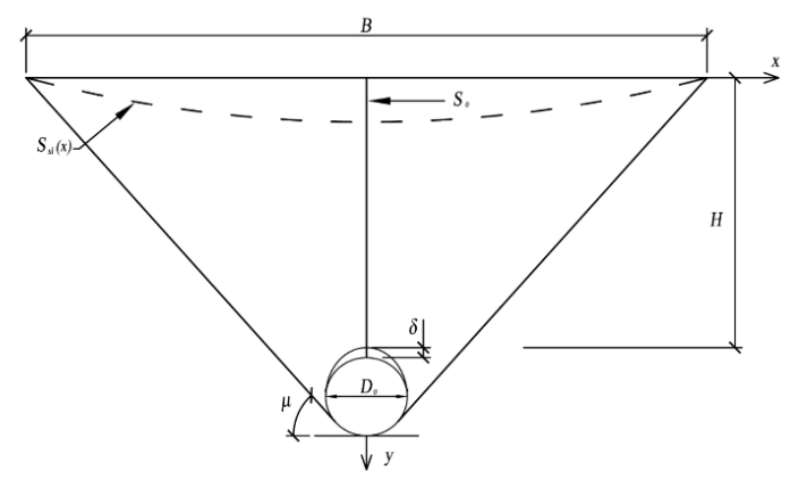

$S_{0}$ - maximum subsidence of the earth surface that usually occurs directly above the underground cavity;

$B$ - width of the shift through;

$H$ - depth of the roof of the space mined out during tunneling; $D_{0}$ - typical dimensions of underground mining;

$\mu$ - boundary shift angle (shift angle of the lines connecting the mining boundary with boundary points of the shift through); $\delta$ - technological discrepancy (difference between the actual diameter of the mined out space and the external diameter of the tunnel lining).

Figure 8. Diagram of a subsidence trough above an underground tunnel (Buildings and structures on undermined territories and slumping soils 2012)

The shallow Universytet station is unique; here, for the first time, a two-level entrance hall was designed and built (Fig. 9). For deep-bore tunneling from this station to the deep Istorychnyi Muzei station, the ЩН-1 tunneling shield with extruded lining was used, which previously proved itself as an effective tool. During transition from shallow to 
deep levels, tunnels had to decline by $40 \mathrm{~mm}$ (maximum permissible gradient) per meter run. During construction of tunnels under old buildings in the city center and the Shevchenko garden, mining works had to be carried out with utmost caution. For the most part, they were performed very professionally: even though the maximum permissible values of surface subsidence equaled $100 \mathrm{~mm}$, real subsidence of the surface did not exceed $6 \mathrm{~mm}$.

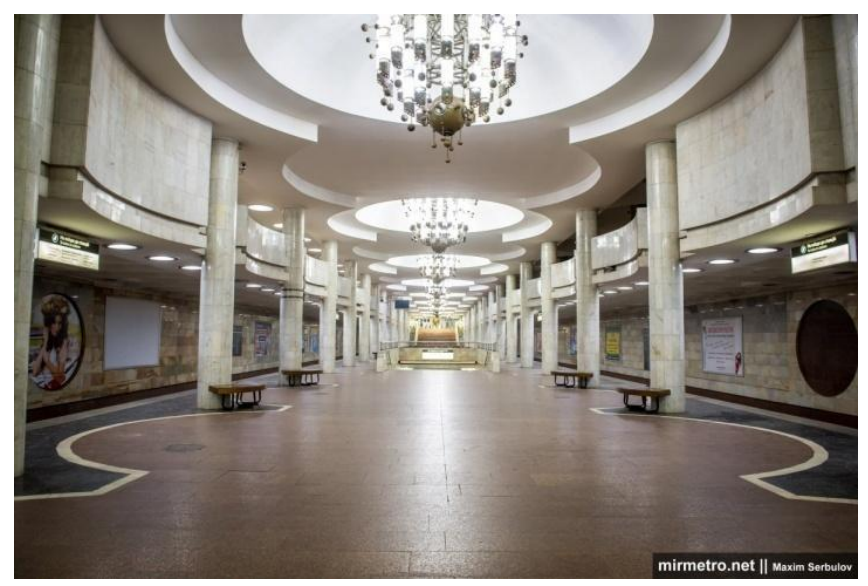

Figure 9. Universytet station. Photo credit: http://www.mirmetro.net/kharkiv/cruise/02/11_universytet

When conducting deep-bore tunneling in dusty clays with low thickness $(5-7 \mathrm{~m})$ common for middle terraces, roof undercutting may occur with the inrush of several cubic meters of ground. Caverns that form by infiltration of precipitation create a risk of development of microsuffosion processes in the soil body and subsequent surface subsidence or even collapse. A similar incident occurred near the foundation of the Ukraine cinema and concert hall in the Shevchenko garden. A hole with the diameter of approximately five meters threatened to cause the unique building to collapse. A method for eliminating the emergency situation was proposed by professor G.G. Strizhelchik (co-author of this article). The hole was filled with sand, and simultaneously a large quantity of water was introduced, which allowed filling all underground cavities and eliminating the danger.

Cases of shallow tunneling under or near existing buildings present a greater challenge. In each case, significant preparatory works must be conducted, which depend not only on the geological characteristics of the relevant ground but also on the design features of the building. Geological hazards include possible disturbance of engineering structures, up to collapse during construction of underground structures, as well as long-term vibration dynamic influences of moving trains by tunnel operation.

\section{Technogenic Fill-up Grounds}

Significant difficulties arise when constructed metro lines must cross ravines and gullies. For instance, the Naukova station was constructed using the cut-and-cover method on the site of a filled ravine. Hydrogeological conditions of this location were favorable for construction: grounds in this area were dry, thus, there was no need for arduous and costly dewatering works. This is why construction of the Naukova station went much faster than construction of other stations at the initial section of the Oleksiivska line. Nevertheless, construction workers received a very unpleasant surprise: during excavation of a pit, a large waste disposal area was discovered, and it took a long time to load and remove the waste using dump trucks.

Crossing an underground water flow after a period of temporary construction dewatering is completed may lead to the barrage effect of metro structures and create a risk of flooding the areas located upstream. This phenomenon is related not only to penetration of water into basements of houses, underground parking spaces etc., but also to changes in condition and properties of grounds, which naturally has a negative impact on the urban development projects. Fillup grounds often contain household and industrial waste, which increases corrosive aggressiveness of the soil towards concrete and metals. For instance, during operation of the metro system near the Naukova station and at the section between the 23 Serpnia and Oleksiivska stations (Fig. 10), new technogenic aquifers emerged in the filled gullies, and the groundwater began to sip into underground parking spaces of high-rise buildings. In these cases, design projects didn't take into consideration such factors as reduction of permeability with the course of time, influence of extreme precipitation patterns, decrease of flow volumes and appropriate increase in infiltration feeding groundwater within the drainage area.

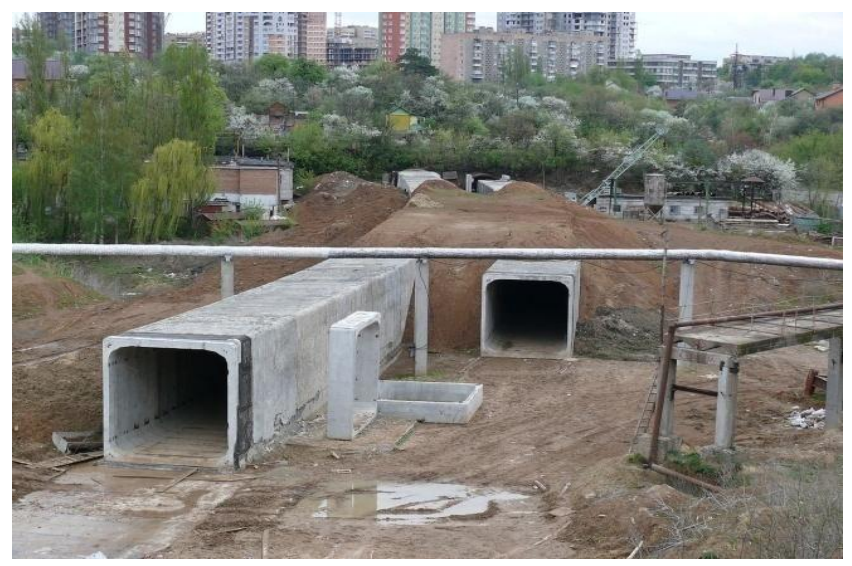

Figure 10. Construction of tunnels through the Oleksiivska ravine between the 23 Serpnia and Oleksiivska stations. Photo source: KHARKIV Today, https://ua.news/ru/yevrosoyuz-profinansuyebudivnitstvo-harkivskogo-metro/

\section{High Noise and Vibration Impact}

During construction of metro objects in the vicinity of existing buildings, violations of sanitary and hygienic standards in regard to noise and vibration may occur, which require taking special measures. For instance, construction of the Naukova station required driving in 172 piles, most of them close to the buildings of the Kharkiv National University of Radioelectronics and the Research Institute 
Giprostal. These works are associated with high noise and vibration impact. Due to strong vibrations, plaster work could fall off of buildings, and there could be malfunctions by operation of sensitive equipment in the mentioned scientific institutions. This is why special boreholes were drilled during construction, and piles were installed in these boreholes, which significantly reduced the vibration impact of the pile driver.

\section{Areas of High Terraces}

In the areas of high terraces, metro stations and tunnels are located in the layer of clays and clay loams, which is a favorable factor. The groundwater level usually lies below 8-10 $\mathrm{m}$ and has almost no effect on the objects under construction. For the construction purposes, mainly the cutand-cover method is used. Geological hazards during construction may be related to subsiding soils that can occur locally on high terraces. Construction in subsiding soils was carried out taking into account the requirements of the relevant regulatory documents, and for the most part, did not cause any serious problems.

\section{Zones of Geological Risks}

As a result of analysis and generalization of the presented material, we have identified the following zones of geological risks that occur during construction and operation of shallow metro systems under the conditions typical for Kharkiv (Fig. 11).

Zone A (high geological risks). Areas with high natural groundwater level (constantly and periodically flooded with the groundwater). This zone is associated with floodplains and low terraces of rivers formed in fine dusty, loamy and dirty sands. The groundwater level may be at the depths from 0 (in the immediate vicinity of river beds and wetlands in the floodplain) to 5 and more meters with increased distance from rivers. Construction is conducted using both the cut-and-cover and deep-bore tunneling methods.

Geological hazards in zone A are connected to wide spreading of quicksands, the possibility of "flotation" of underground structures (stations), the barrage effect of underground structures, the dehydration-gravitational subsidence of the soil body by long-term dewatering.

Zone B (average geological risks). Areas of development of dusty clays with low thickness, by deepbore tunneling under existing buildings. Areas of crossover with ravines and gullies. This zone is located on middle terraces of rivers above floodplains. The geological structure comprises predominantly loess-like loams with an underlying layer of sands. The groundwater level lies at the depths of 4-8 m.

Geological hazards in zone B are connected to the undermining of built-in territories, the expansion of technogenic fill-up grounds when crossing ravines and gullies and the possibility of the barrage effect.

Zone $\mathrm{C}$ (low geological risks). Areas of high terraces with thick layers of clays and clay loams. The groundwater level lies at the depths of $8-10 \mathrm{~m}$ or more and has virtually no effect on the constructed objects. Construction is conducted using mostly the cut-and-cover method.

High noise and vibration impact by construction and operation of metro systems is possible in all identified zones.

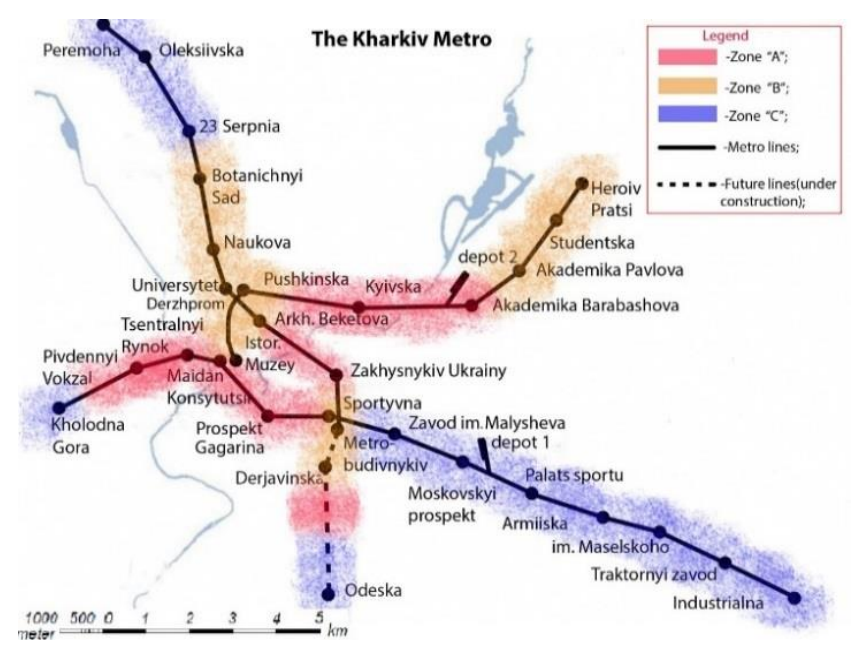

Figure 11. Map showing zones of geological risks for metro structures in Kharkiv

\section{Geological Hazards by Planned Extension of the Oleksiivska (Green) Metro Line}

Currently, a project has been developed, and preparations are on the way for the $3.5 \mathrm{~km}$ long extension of the Oleksiivska (green) metro line from the existing Metrobudivnykiv station to the planned Odeska station (Fig. 1). In this regard, a need has emerged to solve a number of geotechnical problems.

After studying the design and survey materials and conducting an on-site inspection of the area, we (Strizhelchik and Iegupov 2017) have identified a number of natural and technogenic factors as well as geological hazards associated with them, which require making special decisions:

- wide spreading of soft and specific grounds on the location, which complicate construction conditions;

- $\quad$ high groundwater level in certain areas;

- threat to several buildings and structures, under which shallow tunnels will be constructed (unstable roof, taking into account vibration impacts) (Fig. 12);

- possible barrage effect on the underground water flow in the area where deep-bore tunneling will be conducted (Fig. 13);

- $\quad$ risk of thixotropic liquefaction and inrush of weak grounds into the tunnel heading;

- large zone under influence of the construction and systematic dewatering, which creates a risk of surface subsidence and damage to engineering structures of buildings in the area where application of the cut-and-cover method is planned;

- vibration impact on the grounds in foundations of buildings and structures. 

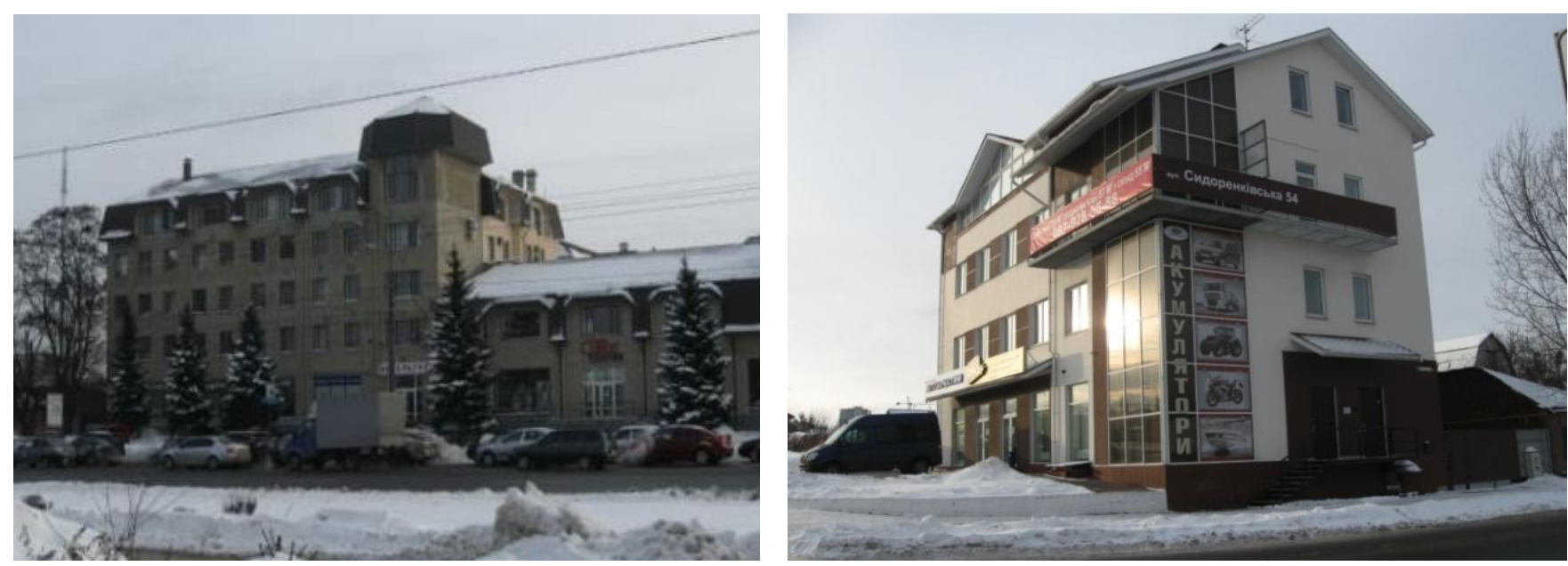

Figure 12. Buildings located directly over the planned tunnels (photos taken by the authors)

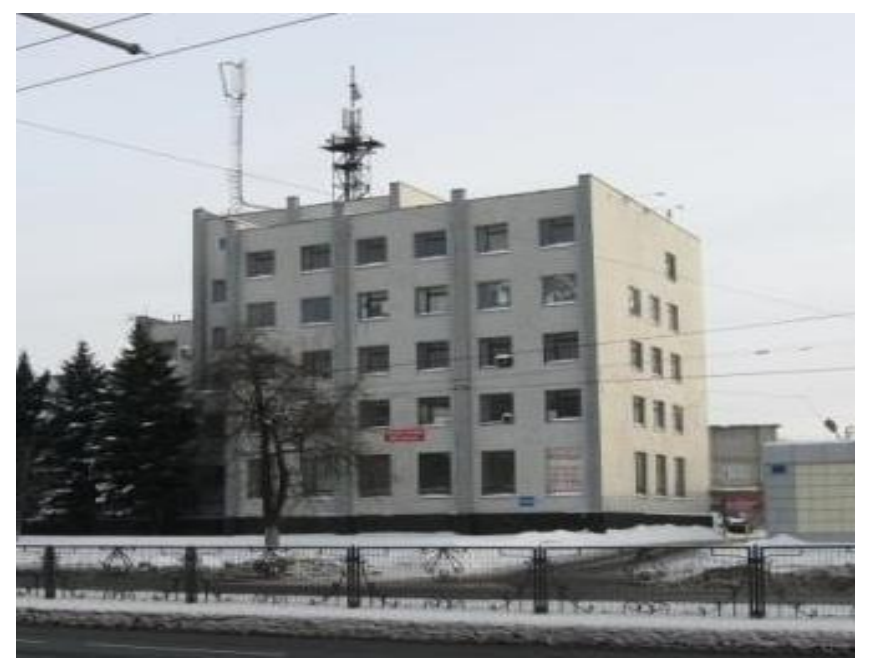

Figure 13. Complex of administrative and warehouse buildings located in the zone of possible barrage effect where the tunnels would cross the Hlybokyi Yar ravine (photo taken by the authors)

The engineering and geological conditions are complicated due to the fact that the planned metro route passes through several geomorphological elements (three terraces of the Lopan river) with different geological structure as well as crosses the Hlybokyi Yar ravine and the filled Sychovskyi gully.

The engineering and geological cross-section of the area along the route obtained during a survey allows isolating 34 engineering and geological elements. The grounds are heterogeneous based on lithological composition, origin, textural and structural features and established type. They significantly differ from each other based on physical and mechanical properties and conditions of occurrence; the ground thickness can suddenly change, sometimes, grounds occur in the form of lenses. Within the analyzed layer, there are two aquifers with irregular mode and the possibility of development of negative engineering, geological and hydrogeological processes, both during construction and operation of objects. In accordance with the applicable regulatory documents, System of reliability and safety of building objects 2007, ground conditions fall into the highest category of difficulty, III a.

The difficulty of construction conditions is related to wide spreading of water-bearing, semi-stable and unstable as well as dry, subsiding grounds in certain areas; presence of operated railway tracks and numerous utility lines. The fact that it is impossible to close Haharina Avenue, one of the most important city roads, for the construction period has determined the deep-bore tunneling method as the one to be used during construction of tunnels between the Derzhavinska and Odeska stations with the help of a mechanical tunneling shield.

One of the most important geological hazards at the crossover between tunnels and the Hlybokyi Yar ravine is high groundwater level of up to $0.5 \mathrm{~m}$ from the surface, which requires taking a number of special measures when tunneling under said level. These measures include: construction dewatering that ensures the possibility of using the cut-and-cover method during construction of support structures; creation of a culvert or a drainage system in order to prevent the barrage effect and flooding of buildings located upstream from the underground water flow.

The construction dewatering project did not take into account the possibility of development of dehydrationgravitational processes in and under foundations of existing buildings and structures. Besides, presence of water-bearing dusty sands carries the risk of tunnel flooding during construction and setting up highwall slopes of pits. In this regard, if such lenses are present, it is necessary to use a larger network of wellpoints or needle-filter units. To exclude a negative impact on the environment due to the barrage effect of the metro system on the underground water flow in areas where said flow goes deeper into the aquifer, it is necessary to use drainage.

Vibration impacts on grounds during construction may cause thixotropic liquefaction of dusty clays and fine-grade sands as well as corresponding flooding of pits and tunnels through the liquefied ground mass. Due to possible negative impact of vibration from running metro trains on adjacent buildings and structures, it is necessary to develop and use special protective measures. 
As a result of analysis and generalization of the design and survey materials for the extension of the Oleksiivska line to the Odeska station, we have identified three zones of geological risks. The section from the Metrobudivnykiv station, including the Derzhavinska station, to the Hlybokyi Yar ravine can be categorized as zone B (average geological risks); the section where tunnels cross said ravine can be categorized as zone A (high geological risks); and the section from the Hlybokyi Yar ravine to the Odeska station can be categorized as zone $\mathrm{C}$ (low geological risks) (see Fig. 11).

Let's examine in detail one of the most significant geological hazards expected on the planned line.

\section{Quantitative Assessment of the Barrage Effect on the Underground Water Flow}

The barrage effect or groundwater ascent occurs when the underground filtration flow is blocked by various underground structures. Usually, it manifests itself as a surge of the groundwater level in front of an impenetrable (or lowpermeability) barrier and a relevant decrease of the ground- water level behind said barrier. This phenomenon is similar in action to dams and barrages blocking the river flow.

The barrage effect has been observed in a number of objects (metro tunnels, stations), where the groundwater level rose and, in some cases, resulted in flooding of areas and adjacent buildings and structures, deformation of earth foundations and other adverse consequences. The importance of evaluating the affluent value based on the barrage effect is emphasized in several applicable regulatory documents, which contain requirements regarding the necessity of monitoring the changes of hydrogeological conditions during and after the construction period. Changes in the hydrogeological conditions are predicted based on analytical calculations or using mathematical modeling of filtration processes by numerical methods.

Let's examine the changes that occur in the underground water flow in case of the barrage effect. The greatest affluent occurs directly in front of the underground barrier blocking the filtration flow, thus, two zones of the affluent influence emerge: frontal $\boldsymbol{L}_{\boldsymbol{F}}$ (Fig. 14) and lateral $\boldsymbol{L}_{\boldsymbol{L}}$ (Fig. 15).

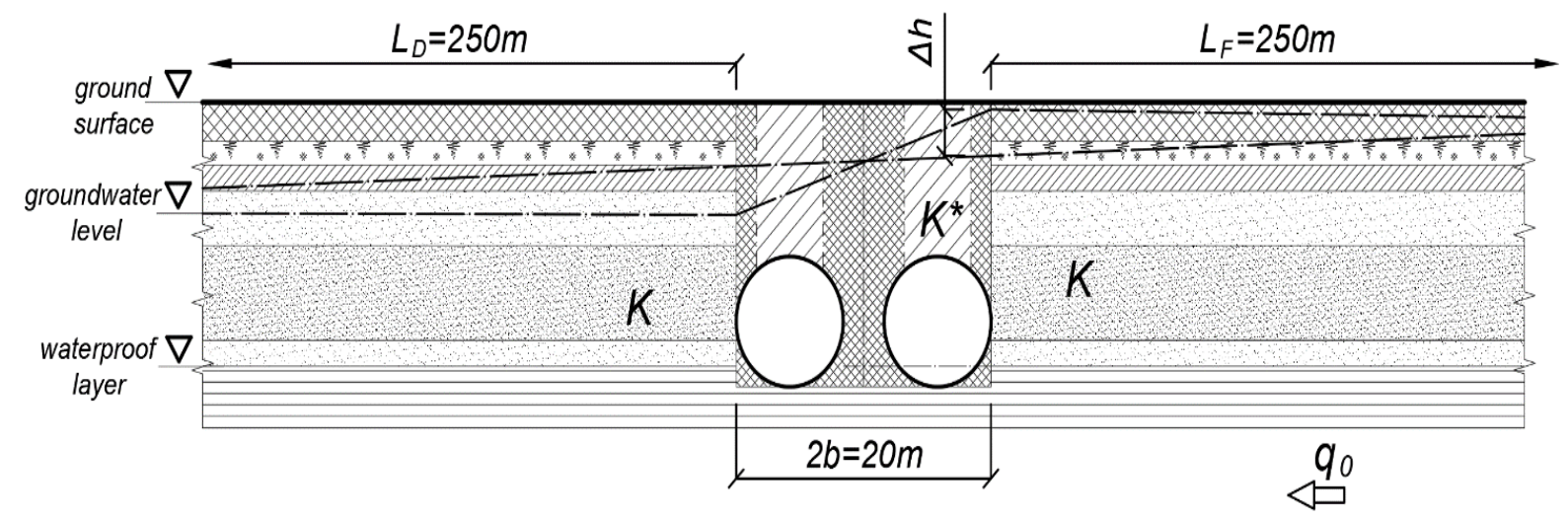

Figure 14. Schematic cross-section in the affluent spot due to the barrage effect of the underground barrier (tunnels and adjacent structures

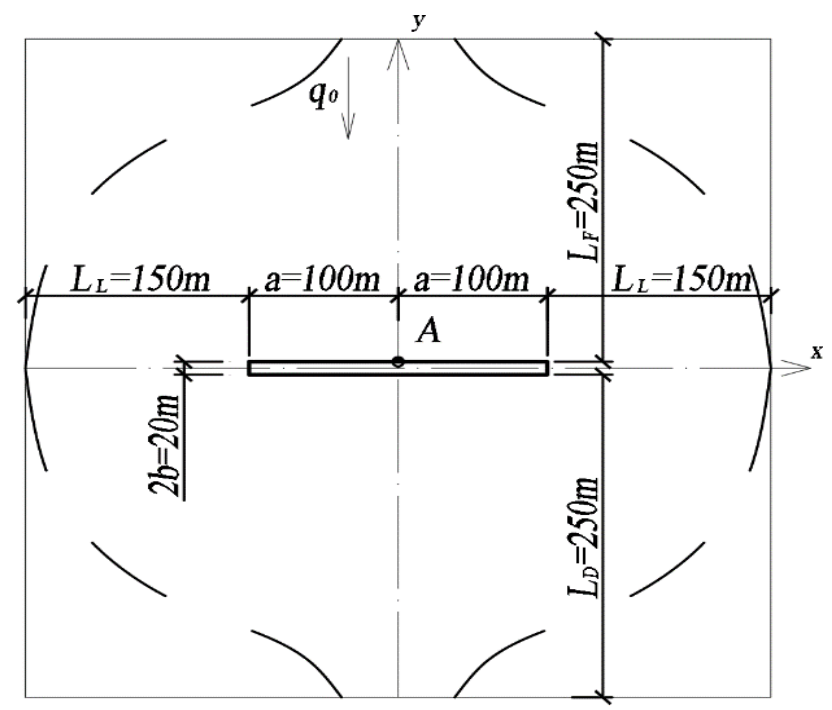

Figure 15. Diagram of the impact of the underground barrier on the underground water flow
Non-stationary filtration of an underground water flow can be described using the non-linear equation famous in the filtration theory Boussinesq 1903:

$$
\frac{\partial}{\partial x}\left(h \frac{\partial H}{\partial x}\right)+\frac{\partial}{\partial y}\left(h \frac{\partial H}{\partial y}\right)=\frac{\mu}{\kappa} \cdot \frac{\partial H}{\partial t}
$$

where, $\boldsymbol{x}, \boldsymbol{y}$ - space coordinates;

$h$ - intensity of the underground water flow, m;

$H$ - affluent function, m;

$\mu$ - coefficient of gravitational capacity of the layer, unit fraction;

$\kappa$ _ filtration coefficient, $\mathrm{m} / \mathrm{day}$.

The affluent value based on the barrage effect by established filtration of flow can be calculated approximately in a linearized setting using the I method (Boussinesq method). This method of linearization when calculating the affluent of the groundwater level was substantiated by Polubarinova-Kochina 1952 and Kuranov 1982, 1984 as the most approximate to a non-linear 
solution.

The analytical method for calculating the affluent based on underground structures was developed by Sologaev 1992, 2002, who substantiated the approximation of rectangular structures and buildings, which create the barrage effect in the process of non-stationary filtration of groundwater, to elliptical shapes.

The barrage effect from an isolated rectangular structure, under which the nominal coefficient of ground filtration has decreased from the initial value $\mathrm{k}$ to $\mathrm{k}^{*}$, can be calculated Sologaev 2002 as changes in the groundwater level (see Figs. 14 \& 15) using the formula:

$$
\begin{aligned}
& \square h=\frac{q_{0} \cdot \sigma \cdot \gamma \cdot a}{k \cdot h_{c}\left(\xi^{2}+\gamma^{2}\right)} ; \\
& \sigma=(1-\eta) /(1+\eta) ; \quad \eta=k_{*} / k ; \\
& \xi=(x \pm a) /(a+b) ; \quad \gamma=(y \pm \beta) /(a+b) ; \\
& \alpha=\left(\frac{1}{2}\left[\sqrt{\left(x^{2}-y^{2}-a^{2}+b^{2}\right)^{2}+4 x^{2} y^{2}}+x^{2}-y^{2}-a^{2}+b^{2}\right]\right)^{0.5} ; \\
& \beta=\left(\frac{1}{2}\left[\sqrt{\left(x^{2}-y^{2}-a^{2}+b^{2}\right)^{2}+4 x^{2} y^{2}}-x^{2}+y^{2}+a^{2}-b^{2}\right]\right)^{0.5} ;
\end{aligned}
$$

where $q_{0}$ - specific rate of a natural underground water flow; $h_{c}$ - average groundwater capacity; $\xi, \gamma$ - relative coordinates of the elliptical cylinder (when determining " $\xi$ ”, the "+" should be used for $\mathrm{x}>0$ and the "_" sign for $\mathrm{x}<0$; likewise, when determining " $\gamma$ ", the " + " should be used for $y$ $>0$ and the "-" sign for $y<0$ ).

Accordingly, the frontal influence zone (Figs 14 \& 15) to a precision of the groundwater level of $10 \%$ or $5 \%$ can be determined as:

$$
L_{F}=L_{D}=(2.5 \ldots 3) a
$$

The frontal influence zone of the barrage affluent $L_{F}$ is measured from the edge of the structure.

Accordingly, the lateral influence zone (see Fig. 14) to a precision of the groundwater level of $10 \%$ or $5 \%$ can be determined as:

$$
L_{L}=(1.5 \ldots 2) a
$$

This formula is confirmed by model experiments.

If the direction of the underground water flow is at an angle to the underground barrier, then the flow vector $\boldsymbol{q}_{0}$ is divided into two components by axes of coordinates, and the affluent values are calculated for each component using the formula and are added together using the principle of superposition.

Let us present an example of calculating the barrage effect of metro tunnels in the area where said tunnels block the underground water flow at the crossover of the Hlybokyi Yar ravine. In the middle, tunnels are located on the surface of a waterproof layer; in the northern part, tunnels are shallower, and the depth of the roof of the waterproof layer increases; in the southern part, the tunnels pass through the waterproof layer. Thus, the maximum barrage effect will occur in a small middle area, which was used for calculation.

Figure 16 shows a fragment of a hydrogeological depthto-water map. It demonstrates the natural position of the groundwater level prior to construction of metro tunnels. The average slope of the earth surface and the groundwater level in the examined area equals $\boldsymbol{I}_{\boldsymbol{s}}=\boldsymbol{I}_{\boldsymbol{g} \boldsymbol{w} \boldsymbol{l}}=\mathbf{0 . 0 2}$. The average groundwater capacity equals $\boldsymbol{h}_{e}=\boldsymbol{h}_{\boldsymbol{c}}=\mathbf{1 1 . 5 m}$. The ground filtration coefficient equals $\boldsymbol{k}=0.9 \mathrm{~m} /$ day .

The underground water flow is at a certain angle to the tunnel axes, accordingly $\boldsymbol{j}=\mathbf{9}^{\boldsymbol{0}}$. Calculated dimensions of the barrage barrier are: length $2 a=200 \mathrm{~m}$, width $2 b=\mathbf{2 0} \mathbf{m}$.

Having met an impermeable inclusion (underground tunnels and support structures), the underground water flow creates zones of increased groundwater level (affluent) to the east of the station and a zone of decreased groundwater level to the west of the station. Calculation of the affluent based on the barrage effect of tunnels to a precision of $10 \%$ corresponds to precision of initial data of the engineering and hydrogeological surveys.

The zone of frontal influence on the underground water flow to a precision of $10 \%$ when calculating the groundwater level using the formulas $(3,4)$ :

$$
L_{F}=2.5 a=2,5 \cdot 100=250 \mathrm{~m}
$$

The zone of lateral influence on the underground water flow is determined using the formula:

$$
L_{L}=1.5 a=1,5 \cdot 100=150 \mathrm{~m}
$$

Concrete walls of the tunnels are waterproof, therefore, the filtration coefficient of the walls equals $\boldsymbol{k}^{*}=\boldsymbol{0}$, and the parameters in the formula (2) are:

$$
\begin{aligned}
& \begin{array}{l}
\eta=k_{*} / k=0 \\
\sigma=(1-\eta) /(1+\eta)=1 ;
\end{array} \\
& \text { If } x=0 \text { and } y=b \text {, the maximum addition } \\
& \text { nt) of the groundwater level } \mathrm{D} h_{\max } \text { in } \\
& \text { 3) is determined using the formula (2), } \\
& \text { fied to: } \\
& \square h_{\max }=\left[q_{0} /\left(\mathrm{k} \cdot \mathrm{h}_{c}\right)\right] \sigma \cdot a \cdot \cos \varphi= \\
& =I_{r} \cdot \sigma \cdot a \cdot \cos \varphi=0,02 \cdot 1 \cdot 100 \cdot \cos \varphi=1,98 M
\end{aligned}
$$

If $x=0$ and $y=b$, the maximum additional increase (affluent) of the groundwater level $\mathrm{D} h_{\max }$ in point $\mathrm{A}$ (see Fig. 13) is determined using the formula (2), which can be simplified to:

The cosine allows accounting for the angle of the underground water flow relative to the axis of the examined tunnel section (see Fig. 15). Since the angle $\boldsymbol{j}=\mathbf{9}^{\boldsymbol{0}}$ is slight, the tunnel structure almost doesn't decrease the affluent relative to the direction of the underground water flow.

The value $\mathrm{D} h_{\max }$, which equals almost two meters, shows that, in this spot, the groundwater will almost reach the surface, and this could cause swamp formation. Therefore, in order to intercept the groundwater and prevent the barrage effect, we recommend placing a horizontal pipe drainage along the eastern side of the tunnels crossing the Hlybokyi Yar ravine. 


\section{Conclusions and Recommendations}

Based on the above, we can make the following general conclusions:

Geological hazards during construction of shallow metro systems are related both to the geological characteristics of certain areas and the methods for conducting works.

The greatest geological hazards occur in areas with high natural groundwater level. By sudden adverse changes of hydrodynamic conditions, geological hazards may increase and even result in dangerous incidents. By shallow placement of underground objects in structurally unstable grounds, risks may be much higher than the economically feasible values. The projects that envision construction of new metro systems must include measures aimed at preservation of hydrodynamic conditions in the areas that have already been developed

The results of evaluation of geological hazards, which we have obtained, can be used for the purposes of designing and constructing underground objects in conditions similar to those typical for Kharkiv.

When examining the problems related to construction of metro systems in rough engineering, geological and anthropogenic conditions, it should be noted that a number of engineering, ecological and economic problems may arise by almost any underground construction in the conditions of a large city, and to find an optimal solution to these problems, a wide range of highly qualified specialists from leading scientific organizations and specialized departments of higher education institutions must be engaged.

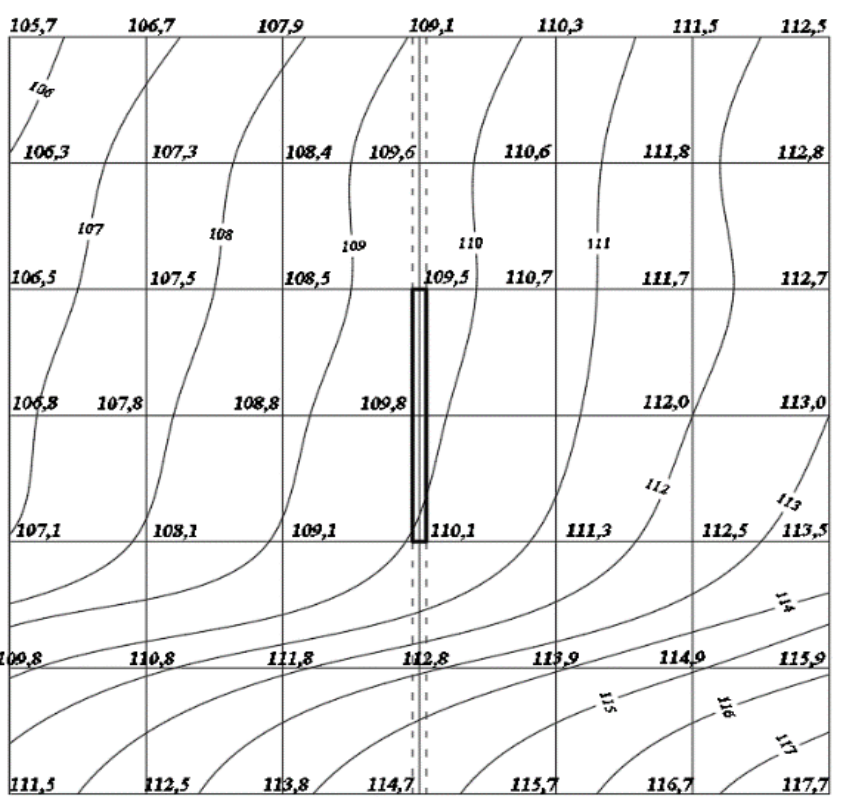

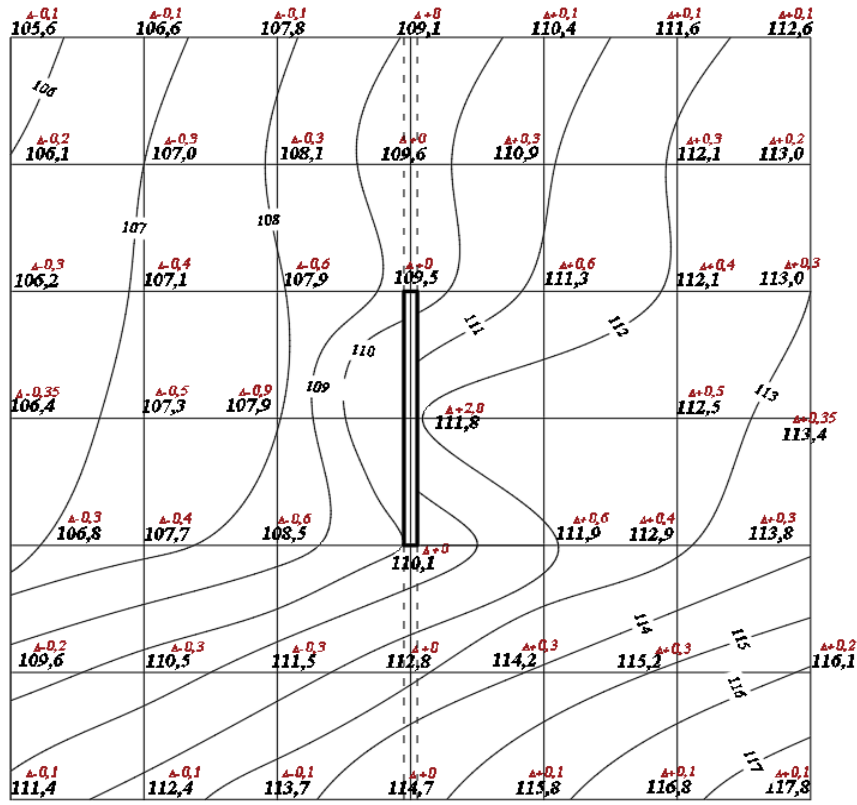

$\mathrm{b}$

Figure 16. Depth-to-water maps before (a) and after construction of tunnels (estimates) (b) at the crossover of the Hlybokyi Yar ravine

\section{Acknowledgment}

The authors are grateful to our colleagues from the Department of Geotechnics and Underground Structures for their comments on the manuscript.

\section{References}

Abelev, M.Y., 1983. Construction of Industrial and Civil Structures on Weak Water-Saturated Grounds. Moscow, Stroyizdat, 248p. (in Russian)

Abramchuk, V.P., S.N. Vlasov and V.M. Mostkov, 2005. Underground Constructions. Moscow, TA Engineering, 470p. (in Russian)

Bielecki, R. and R. Berger, 1998. Das Sicherheitskonzept für den Bau der 4. Röhre des Elbtunnels in Hamburg. Tunnelbau. Berichte 5 Internationales Tunnelbau-
Symposium München. Deutschland, Im Rahmen der Bauma, 1-2: 27 - 32.

Bondarenko, V.I. and A.N. Roenko, 1996. Problems and Prospects for the Development of the Large Cities Underground Space. Reports of the International Conference, June 19 - 20, 1996, Dnepropetrovsk, 137p. (in Russian)

Bondarik, G.K., 2007. Engineering Geodynamics. Moscow, KDU, 440p. (in Russian)

Boussinesq, J., 1903. Recherches théoriques sur l'écoulement des nappes d'eau infiltrées dans le sol et sur le débit des sources. Comptes Rendus Acad. Sci. Paris, J. Math. pures et appl., 1903 - 1904. 10: 5 - 78, 363 - 394 (in French)

Brodin, A., 1998. Risk Analysis and Safety Concept, Norra and Sodra Lanken (Northern and Southern Link). Underground Construction in Modern Infrastructure. 
Rotterdam, Balkema, 49 - 53p.

Buildings and Structures on Undermined Territories and Slumping Soils, 2012. SP 21.13330.2012. Moscow, Standartinform, 68p. (in Russian)

Demchyshyn, M.G., 2004. Technogenic Impacts on the Geological Environment of Ukraine. Kyiv, Gnosis LLC, 156p. (in Russian)

Ecological Geology of Ukraine: Reference Guide, 1993. (Shnyukov, E.F., M.G. Demchyshyn, V.M. Shestopalov, E.A. Yakovlev, G.G. Strizhelchik and others]. (Institute of Geological Sciences, NAS of Ukraine). Kiev, Naukova Dumka, 407p. (in Russian)

Eskesen, S.D. and J. Kampmann, 2000. Risk Reduction Strategy in Urban Tunneling: Experience from the Copenhagen Metro. AITES-ITA World Tunnel Congress, 161 - 166p.

Giginyak, E.I., 2009. Construction of an inclined course of a metro station with the help of the Herrenknecht TPMK in St. Petersburg. Metro and Tunnels, 5: 4 - 5 (in Russian)

Iegupov, V.Iu. and O.V. Kichaeva, 2016. Basics of Geology and Engineering Geodynamics. Kharkov, "KhNUMG", 273p. (in Russian)

Kuranov, N.P., 1982. On the relationship between hydrodynamic and hydraulic filtration theories and ways of their linearization in the study of flood problems underground waters. Engineering Protection of Territories. Moscow, VNII VODGEO, 5 - 20p. (in Russian)

Kuranov, N.P., 1984. Linear models of the theory of hydrodynamic filtration. Reports of the USSR Academy of Sciences. Moscow, Science, 278(2): 309 - 313. (in Russian)
Polubarinova-Kochina, P.Ya., 1952. Theory of Groundwater Movement. Moscow, Gostech-Publish, 676p. (in Russian)

Sologaev, V.I., 1992. Forecast and Prevention of under Flooding by Underground Waters of the Omsk Metro and Adjacent Territory (1st line 1): Report on R \& D. Omsk, SibADI, 85p. (in Russian)

Sologaev, V.I., 2002. Filtration Calculations and Simulation of Protection from Underground Water in Urban Construction. Monograph. Omsk, SibADI, 416p. (in Russian)

Strizhelchik, G.G. and V.Iu. Iegupov. 2017 Problems of subway construction in complex engineering and geological conditions by the example of the city of Kharkiv. Poltava National Technical Yuri Kondratyuk University. Academic Journal, 2(49): 195-200.

Strizhelchik, G.G., V.Iu. Iegupov and I.V. Hrapatova, 2017. Engineering Geology. Kharkov, "Typography Madrid", 484p. (in Russian)

System of Reliability and Safety of Building Objects, 2007. Scientific and technical support of construction objects. DBN V.1: 2 - 5. Kyiv, Minregionbud of Ukraine, "Ukrahrbudinform", 71p. (in Ukranian)

Theoretical Bases of Engineering Geology, 1985. Geological Basis. (Ed. by Acad. Sergeev E.M. Moscow, Nedra, 332p. (in Russian)

Vlasov, S.N, L.V. Makovsky and V.E. Merkin, 2000. Emergencies in the Construction and Operation of Transport Tunnels and Subway/With the participation of Kuplis A.E., Sarabeev V.F., Torgalov V.V., 2nd edition, supplemented. Moscow, TIMR, 198p. (in Russian)

Zlochevskaya, R.I., 1969. Associated Water in Clay Soils. Moscow, Moscow State University, 84p. (in Russian) 